\title{
資料 米国におけるなたね油の食用認可に際して
}

\author{
鍵 \\ 譲 \\ カナダ大使館商務部（東京都港区赤坂 7-3-38）
}

本年 1 月 28 日付をもって, 米国においてエルカ酸含 有量 $2 \%$ 以下のなたね油が GRAS（一般に安全と認め られる基準) 認可となり, 食用に使用が可能となった。 米国が $2 \%$ という基準を打ち出したことから，世界的尺 度は $2 \%$ をもって云々されることになろう。欧州でも国 により，3\%とか $5 \%$ という具合で, この点世界的合意 は未だ確立されていない。各国の規制の状況については 別の機会に譲りたい。ここでは今回の FDA（米国食品 医薬品局）の決定が与える影響等をカナダの立場を中心 に，大ざっぱに取り上げてみたい。カナダでは今回の決 定前から事あるごとに，さまざまな見方が伝えられてき たが，大方は肯定的受け止め方である。

まず油の面から第 1 にカノーラ（低エルカ酸・低グル コシノレートのカナダなたねの総称）油市場がすぐ南の 隣国に開けたことだ。ここ当分はカナダ産カノーラ油の 対米輸出での優位は続こうが, やがて米国自身も含め力 ナダ以外の諸国も，この単一国としては世界最大の市場 に参入してこよう。1983/84 年度 (83 年産中心) のカナ ダ産カノーラの輸出向エルカ酸含有量は平均值で $0.8 \%$ (因みに 1984 年産は $0.6 \%$ ) であり, 今回の $2 \%$ とい う尺度からはオーバースペックであり，実務面において この優位性を活用する手立てを検討すべきであろう。

さてこのような新市場の出現から，第 2 に東部カナダ でのカノーラ油利用が促進されよう。東部ではもともと 搾油用大豆を米国から輸大してきた。かつて 1979 年マ 一ガリン製造協同組合訪加視察団をモントリオール郊外 のマーガリン工場に案内したとき, 当時その工場はカ， ーラ油を使っておらず，本来ならお見せしたくない工場 であったが，カノーラ油の東部での普及状況をありのま まに見ていただくことにした。因みに 1979 年はカナダ なたねのダブルロー（低エルカ酸・低グルコシノレー ト）切り換えの中間に当たっていた。

第 3 にこれを契機にカノーラ油の用途開発が促進され よう。すでにカナダ国内の食用植物油の約 $50 \%$ をカノ 一ラ油が占めており，現状用途だけでは，当分限界とみ た方が無難である。すでにカナダ国内の控油規模が日本 のそれとほぼ同じ位になった今日，このこと注必至であ る。用途を食用におき，低エル力酸化に努めてきたが， 待望の米国市場開禁を機に，食用以外の用途も検討すべ きであり，今さら歴史の歯車をむかしに戻すことを示唆 する意図は毛頭ないが，例えばカノーラ油の自動車然料 化利用等はぜひ続けなければなるまい。COM (石炭・重 油混焼）やCWM (石炭・水混焼) の商業化の技術も,
石油危機に加速されたことを想起し，ひとつの節目とし て把えるべきであろう。

第 4 に，これはカノーラミールの点であるが，飼料用 にはすでに対米輸出されているが，この先必要なこと は, 食用としての研究開発の促進である。すなおち植物 性タンパクとしての商業化を本格的に行う必要がある。 それはカナダ国内市場及び輸出市場の開発となるからで ある。1977 年にカナダから官民合同の “新タンパク事 情調査団”の来日があり, 当時設立間もない日本植物蛋 白食品協会の方々とも意見交換等させていただいたにも かかわらず，せっかくの体験が結果的には無為に終わっ てしまったことは残念である。もっとも何でも同時併行 的に研究開発を期待するのが無理なのかもしれない。在 来種に始まり，低エルカ酸化，ダブルロー化と息つく間 むなく邁進してきたが, カノーラミールの食用開発は今 後の大きな課題のひとつである。

第 5 に今回の対米解禁はカノーラ油, カノーラミール のウイニペグ商品取引所への上場早期化を促進しよう。 まず当面は同商取での原料カノーラの取引量の増加が期 待される。先の話だが, やがて米国内で原料生産も一定 水準に達すれば米国内での上場も夢ではなからう。すで に証券分野を初め，世界の取引所の国際的連携が始動し ていることからもこのことは無縁ではないはずである。

最後に原料カノーラの面では, 競合生産国の出現を意 味する。それはまた東部カナダにおけるカノーラ生産を 本格化するであろうし，そうなれば米国と同じく越冬型 なたねの東部カナダでの生産は, 西部カナダでの端境期 を補完し, 日本のもっとも基本的䀣念である安定供給に 大きく貢献することになる。そこで他国産なたねとの差 別化を維持していくためには, 例えばトリプルロー（低 エルカ酸・低グルコシノレート・低繊維）化が必至とな ろう。このことは日本での一般的流通経験からして, 前 述の食用植物タンパク的利用とも無関係ではない。目下 1985 年を初年度とした 5 か年計画 “カノーラと共に成長 しよう”(カノーラ増反増産運動) が展開されつつある中 で, 今後こうした一層の高品質化追求をどのようにして 採り大れ斉合性のあるものにしていくかが課題である。

結論的には, 供給面では西部カナダ, 東部カナダそし て米国等, 今後増産の方向に向からと思われる。世界的 に必要なことはカノーラ油とカノーラミールの新用途開 発である。同じ油脂原料でも大豆に比べ，なたね・カノ ーラ作物の利用はまだまだ開拓の余地は充分にある。 